\title{
IMAGE INFLUENCE BASED ON HALLMARK EVENT
}

\author{
Leon Mohan ${ }^{* 1}$ 《iD \\ ${ }^{* 1}$ Saint Leo University, Florida, United State
}

DOI: https://doi.org/10.29121/granthaalayah.v8.i9.2020.1199

Article Type: Research Article

Article Citation: Leon Mohan. (2020). IMAGE INFLUENCE BASED ON HALLMARK EVENT.

International Journal of Research GRANTHAALAYAH, 8(9), 296-304. https://doi.org/10.29121/granthaa layah.v8.i9.2020.1199

Received Date: 15 September 2020

Accepted Date: 30 September 2020

Keywords:

Tampa

Gasparilla

Destination Image

Travel

\begin{abstract}
Despite Tampa's growing popularity as a travel destination and solid economy, Tampa's image as a vacation preference continues to evolve. This exploration examines the influence of Tampa's Annual Gasparilla event on guest preference of a destination, contrasting first-time and revisit guests' discernments, as well as the individuals who explicitly came to see Gasparilla, or for different purposes. A directed questionnaire was utilized in gathering information from 158 respondents, enabling a pre and post examination of how visiting recurrence and reason for visit (Gasparilla or not) affected picture the perception of the destination. The outcomes demonstrated that perceptions could vacillate significantly after sequential visits, in spite of the fact that the Gasparilla occasion in itself didn't change guest perceptions. Different types of data sources were analyzed in their utilization in persuading the guest to travel to Tampa during this period, uncovering the significance of word of mouth, yet in addition recommending the significance of having a coordinated marketing and advertising program.
\end{abstract}

\section{INTRODUCTION}

The primary guest purpose is to travel to the Tampa Bay area for the beautiful beaches primarily located in Saint Petersburg and Clearwater. Each of these locations are within a 45 minute drive of the center of the City of Tampa. While trying to incorporate other elements of the Tampa Bay region in their marketing of the destination, one of the Tampa's drives has been to endeavor to situate Tampa as a 'city of occasions' through holding major events, for example, the PGA (Professional Golfers Association) Valspar Championship, College Football Championship and Professional Sports teams, for example, the Buccaneers, Lightning and Rays. This likewise incorporates its biggest game, the Super Bowl, which will be held in 2021. The combination of sport and the travel industry isn't new, however such occasions are currently a developing wonder (Getz, 2008), with a considerable amount of activity falling into the category of sport tourism (Kaplanidou and Gibson, 2010)). This investigation attempts to evaluate the impact that the mega event Gasparilla has had on Tampa's attributes and its general brand image. Most research on destination image examine specific components of a destination rather than the entire picture (Konecknik and Gartner, 2007; Tasci, and Gartner, 2007). Few research in this area has been applied to a continuous mega event in a similar context, for example, the yearly Tampa Gasparilla (which as far as levels of effect upon Tampa could be viewed as a mega event), with the ramifications of repeating attendees and participants in addition to media influence in marketing because of its regular occurrence during the same timeframe. In view of this the accompanying goals of this investigation were to: 1 . Determine contrasts in the perceptions of Tampa held by first-

(C) 2020 The Author(s). This is an open access article distributed under the terms of the Creative Commons Attribution License, which permits unrestricted use, distribution, and reproduction in any medium, provided the original author and source are credited. 
Image Influence Based on Hallmark Event

time and repeat visitors to Tampa, pre and post the Annual Tampa Gasparilla; 2. Determine pre and post contrasts in the perceptions of Tampa held by the individuals who explicitly came for Gasparilla, and the individuals who might not attend but came for other reasons; 3. Evaluate how the perception of Tampa held by vacationers after Gasparilla impacts the probability that they would come back to visit Tampa; and, 4 . The impact of different types of data sources on the vacationer's choice to visit Tampa.

\section{GUEST PERCEPTION}

'Until individuals visit a locale, their insight into that spot is totally subsidiary. That doesn't, in any case, keep individuals from having a moderately firm assessment of that area' (Campo-Martinez, Garau- Vadell, \& MartinezRuiz, 2010). Gunn's (1972) proposed that a guest's perceptions of a locale can be influence either by really visiting the locale (natural) or by remotely accepting (external) data from promotions, news reports or by listening in on others' conversations. Gunn clarified a visitor's experience, starting with an underlying mental picture (first stage), to really making a trip to the locale (fourth stage), to a last (seventh) phase of reevaluating these pictures dependent on the experience.

Earlier research has proposed that it requires some investment to change pictures regardless of whether qualities are significantly changed (Beerli and Martin, 2004), credits being an approach to operationalize and measure locale perception by taking a gander at individuals' convictions, thoughts or impressions about the destination (Gartner, 1989). As clarified by Gartner (1993), the degree of noteworthiness, cost and market entrance will have shifting effects on image development: unmistakable instigated (for example customary publicizing, travel images), incognito prompted (for example reports, stories), self- governing (for example news and films), spontaneous natural (for example unsought data from companions and partners), requested natural (for example companions, informal) and natural (for example genuine visit). Ultimately, it is the genuine truth of a visit and number of rehash visits from that point which will change the manner in which individuals see the locale. As to contrasting image observations between pre-guests and post guests, and hence with more noteworthy significance to the Tampa Gasparilla look into, Kim and Morrision (2005), in recognizing changes of images among outside voyagers to Korea after the 2002 World Cup, discovered 11 experimental investigations. Here the main consideration of image change varied - , for example, after a political occasion (Tiananmen Square clash); a visit experience among guests and non-guests (Beerli and Martin, 2004); and after an advertising campaign (King, Chen, \& Funk, 2012) - with the factor of image change in these investigations concentrating on a confined occasion. Further, a typical element of these examinations was the utilization of mail studies to gather information. Another pre and post study on image, however one which concentrated on a one time visit, was directed by Hosany, Ekinci, \& Uysal (2006) on voyagers to a Thai social show; this exploration included personal meetings, and found that the sudden effect on image by the show was not obvious, with no longitudinal impact being evaluated. Gasparilla on the other hand has been Tampa's significant yearly tourist event. Moreover, Gasparilla has not stayed static rather has kept on developing as far as required assets, attention, interest, media inclusion and onlookers. Investigation of the Tampa Gasparilla can possibly uncover changes in Tampa's destination image for years.

Gallarza (2002) recommend that, similar to the case with destination image, the different parts are probably going to be various and differing, broad research ought to be taken to guarantee that all have been revealed. Consequently, basic characteristics were drawn from the writing (Gallarza, 2002; Konecknik and Gartner, 2007; Tasci, and Gartner, 2007) pondering perceptual/psychological assessment (convictions and information about an item) and the effective (sentiments the guests may have about it) (Konecnik, and Gartner, 2007). In looking for traits specific of Tampa, surveys including Tampa

Undergraduate hospitality and tourism students and Tampa Hotel administrators further broadened the things to incorporate attributes, for example, 'Tampa is a beach city, ' 'Tampa has simple entry/travel inside the city, ' 'Tampa has numerous activities, ' and 'Tampa is a vacation destination'. An overview instrument was created dependent on past research (Gallarza, 2002; Tasci, and Gartner, 2007) to reflect image traits, yet in addition number of visits, reason for visits, probability of revisit appearance and sources of data. Bayshore Boulevard in Tampa, was picked as the area to do both the pilot test and campaigning of respondents. The area is heavily utilized and is also the sight of the Gasparilla parade.

Where past research utilized mail studies of a similar example (Beerli and Martin, 2004; Gartner and Shen, 1992), this examination was intended to scrutinize a similar visitor up close and personal in the actual location of 
the event. After pilot testing at the location to ensure reliability and validity a survey of 15 Likert trait explanations was developed. Respondent and interviewee cooperation just as the legitimacy and unwavering quality of the Likert scaling was additionally inspected, as research has recommended discontinuity in the utilization of traits as well as in the organization of gathering data (Beerli and Martín, 2004). Five experienced questioners arbitrarily surveyed participants and visitors upon entering and then leaving Gasparilla event. Those surveyed were given a location to meet the surveyors for the post event survey as well as receive a gift for completing the post event survey.

Respondents were solicited to show their level from understanding or difference on a size of 1 (emphatically dissent) to 5 (unequivocally concur) for each quality attribute. Location of residence was likewise mentioned to determine if they were in fact visitors to Tampa. Earlier research recommends that the more fascinating the event, the further individuals will be travel to encounter it (Funk \& Bruun, 2007). The respondents for this investigation were asked some information about their recurrence of visits to Tampa, with research demonstrating that the more regular the appearances the more mindfulness and awareness about social activities, tourist opportunities and facilities (Beerli and Martin, 2004).

RESULTS Respondent Profile As appeared in Table 1, 85 respondents (53\%) were male and 73 respondents (47\%) were female. Most of respondents were ages 25-34 (47\%) and 35-44 (24\%), and had finished chiefly either secondary school or pre-college (47\%) or college (44\%). Most had salary levels of

$\$ 40,001$ to $\$ 59,000(49 \%)$ or under $\$ 40,000(38 \%)$, and were either living with a roommate(s)/relative (36\%) or a couple with kids living at home (30\%). A vast share originated from Tampa (73\%) or the Southeast (20\%). The occupations of the respondent were decently equally spread among administrative (28\%), management (26\%), executive $(21 \%)$ and specialized staff $(25 \%)$.

\section{RECURRENCE AND PURPOSE OF TRIP}

Respondents were questioned on the number of evenings they would remain in Tampa and the occasions they had been to Tampa (see Table 2). Most remained 1 night (75\%) and had been to Tampa multiple occasions (78\%); for $22 \%$ this was their first time to visit Tampa. The vast majority of the respondents' motivation of visit was for different purposes (54\%), while the rest of the respondents came to see the Gasparilla (46\%), with 62 of the 64 onlooker respondents coming to specifically for Gasparilla.

Table 1: PROFILE OF RESPONDENTS DURING THE 50TH TAMPA GASPARILLA (N=158)

\begin{tabular}{|c|c|c|c|c|c|}
\hline & $\mathrm{N}$ & PERCENTAGE & & $\mathrm{N}$ & PERCENTAGE \\
\hline Gender & & & Household Income & & \\
\hline Male & 85 & $53 \%$ & $<\$ 20,000$ & 5 & 3 \\
\hline Female & 73 & $47 \%$ & $20-39,999$ & 55 & 35 \\
\hline Age & & & $40-59,999$ & 77 & 49 \\
\hline $15-24$ & 25 & $16 \%$ & $60-79,999$ & 30 & 18 \\
\hline $25-34$ & 75 & $47 \%$ & $80-99,999$ & 6 & 3 \\
\hline $35-44$ & 38 & $24 \%$ & $100,000+$ & 5 & 2 \\
\hline $45-54$ & 18 & $11 \%$ & & & \\
\hline$>54$ & 2 & $1 \%$ & & & \\
\hline Education & & & & & \\
\hline High school & 75 & $47 \%$ & & & \\
\hline Vocational & 6 & $3 \%$ & & & \\
Training & & & & & \\
\hline College & 70 & $44 \%$ & & & \\
\hline Postgraduate & 7 & $4 \%$ & & & \\
\hline
\end{tabular}

Table 2: NUMBER OF NIGHTS, REPEAT VISITS AND PURPOSE OF VISIT TO TAMPA

\begin{tabular}{|c|c|c|}
\hline No. of Nights Staying in Tampa & $\mathrm{n}$ & Percentage \\
\hline 1 night & 118 & 75 \\
\hline 2 nights & 34 & 21 \\
\hline
\end{tabular}


Image Influence Based on Hallmark Event

\begin{tabular}{|c|c|c|}
\hline 3 nights & 5 & 4 \\
\hline$>$ 3nights & 0 & 0 \\
\hline$* \mathrm{n}=147$ & & \\
\hline $\begin{array}{c}\text { No. of times in Tampa (including } \\
\text { this time) }\end{array}$ & $\mathrm{n}$ & \\
\hline First time & 35 & 22 \\
\hline Twice & 17 & 11 \\
\hline Third time & 16 & 10 \\
\hline Fourth time & 6 & 4 \\
\hline More than 4 times & 84 & 53 \\
\hline Purpose of visit to Tampa & $\mathrm{n}$ & \\
\hline Gasparilla & 74 & 46 \\
\hline Other purpose & 84 & 54 \\
\hline
\end{tabular}

\section{PERCEPTIONS OF FIRST-TIME AND REPEAT VISITORS}

The aspects of 'opportunity for adventure/excitement', 'good beaches', 'place to undertake study', 'place to do business' and 'wide variety of products' did not score strongly with either group of respondents. While there were mean differences between both groups, an independent sample mean t- test was applied and found that there was a statistically significant difference between the first-time travelers and repeat travelers for the following attributes; 'unique architectural buildings' ( $\mathrm{t}=-3.310 ; \mathrm{p} \leq 0.05)$, 'many interesting local festivals/shows' $(\mathrm{t}=-2.734 ; \mathrm{p} \leq 0.05)$, 'good quality tourist information' $(\mathrm{t}=-2.097 ; \mathrm{p} \leq 0.05)$ and 'attractive enough to tell others on your return' $(\mathrm{t}=2.101$; $\mathrm{p} \leq 0.05)$. While these statistically significant differences between first time and repeat visitors may indicate that the number of visits to a destination can affect its perceived image (Campo-Martinez, Garau-Vadell, \& Martinez- Ruiz, 2010), caution should be shown on making such an analysis, given the relatively small number of attributes with statistically significant differences, warranting further research.

An assessment was attempted to check whether there were noteworthy contrasts in the pre and post view of first-time guests, just as pre and post revisit guests. Table 3 presents 14 image traits utilized on the questionnaire, indicating the mean score (of a 5-point Likert type scaling) of each for first time travelers ( $\mathrm{n}=35$ ) and revisit guests $(n=123)$, and recorded in declining order of rating (significance level). The items of 'Beautiful Weather ', ' Many interesting local festivals/shows ', 'Attractive enough to tell others on your return ', and 'Good quality tourist information' each score a significance level of $<.05$ with regards to the differences between First Time Travelers and Repeat Travelers. While these measurably noteworthy contrasts between first time and repeat guests may demonstrate that the quantity of visits to a destination can influence its apparent image (Campo-Martinez, GarauVadell, \& Martinez-Ruiz, 2010), alert that there should be further research due to the limited number of quality items examined as well as the differences based on destinations.

Table 3: PERCEPTIONS OF FIRST TIME AND REPEAT TRAVELLERS ON ARRIVAL TO TAMPA (N=148)

\begin{tabular}{|c|c|c|c|c|c|c|c|}
\hline & \multicolumn{2}{|c|}{$\begin{array}{c}\text { First time travelers } \\
\mathrm{n}=35\end{array}$} & \multicolumn{2}{|c|}{$\begin{array}{c}\text { Repeat travelers } \\
\mathrm{n}=123\end{array}$} & & \\
\hline & Mean & SD & Mean & SD & Mean differencet - value & $\begin{array}{c}\text { Sig. (2- } \\
\text { tailed) at 5\% }\end{array}$ \\
\hline $\begin{array}{c}\text { Beautiful Weather } \\
\begin{array}{c}\text { Many interesting local } \\
\text { festivals/shows }\end{array}\end{array}$ & 3.60 & .577 & 4.02 & .572 & -0.42 & -3.310 & .001 \\
\hline $\begin{array}{c}\text { Attractive enough to tell others on your } \\
\text { return }\end{array}$ & 3.56 & .821 & 3.20 & .786 & 0.36 & 2.101 & .037 \\
\hline $\begin{array}{c}\text { Good quality tourist } \\
\text { information }\end{array}$ & 3.40 & .913 & 3.74 & .699 & -0.34 & -2.097 & .038 \\
\hline $\begin{array}{c}\text { Lower prices/value for } \\
\text { money }\end{array}$ & 3.40 & .707 & 3.64 & .703 & -0.24 & -1.570 & .119 \\
\hline
\end{tabular}


Leon Mohan

\begin{tabular}{|c|c|c|c|c|c|c|c|}
\hline $\begin{array}{c}\text { Wide variety of } \\
\text { products }\end{array}$ & 3.16 & .624 & 3.38 & .763 & -0.22 & -1.558 & .127 \\
\hline $\begin{array}{c}\text { Ease of accessibility/Transit } \\
\text { city }\end{array}$ & 3.48 & .770 & 3.72 & .684 & -0.24 & -1.536 & .127 \\
\hline $\begin{array}{c}\text { Natural scenic beauty } \\
\text { Rich cultural heritage }\end{array}$ & 3.20 & .645 & 3.46 & .957 & -0.26 & -1.530 & .128 \\
\hline $\begin{array}{c}\text { Opportunity for } \\
\text { adventure/excitement }\end{array}$ & 3.36 & .860 & 3.15 & .869 & 0.21 & 1.087 & .284 \\
\hline $\begin{array}{c}\text { Place to have } \\
\text { meeting/exhibition }\end{array}$ & 3.04 & .841 & 3.19 & .694 & -0.15 & -.931 & .354 \\
\hline Many places of interest to visit & 3.40 & .707 & 3.54 & .781 & -0.14 & -.916 & .366 \\
\hline $\begin{array}{c}\text { Unique cuisine } \\
\text { Good quality and easy } \\
\text { to find hotels }\end{array}$ & 3.68 & .802 & 3.83 & .649 & -0.15 & -.874 & .389 \\
\hline$\quad$ & .712 & 3.69 & .667 & -0.13 & -.849 & .402 \\
\hline
\end{tabular}

Upon leaving Gasparilla, a similar respondent gatherings were again addressed. Their reactions are again positioned in order of the previous table. It was discovered that despite the fact that Tampa's trait of having ' Beautiful Weather ' stayed high for the two groups, other items were reported highly upon arrival: 'Many interesting local festivals/shows', Attractive enough to tell others on your return' and 'Good quality tourist information '. The two groups additionally kept on giving lower scores on ' Rich cultural heritage',' Wide variety of products' and 'Place to have meeting/exhibition.' While there were again mean contrasts between the groups, the significance of the analysis changed upon departure from the event: 'Lower prices/value for money ' $(t=-0.823 p \leq 0.05)$, and ' Many places of interest to visit ' $(\mathrm{t}=0.76 ; \mathrm{p} \leq 0.05)$. This shows despite the fact that the respondent may have finished a first excursion to Tampa, the quantity of revisits to a destination can at present keep on influencing assessments towards image traits. Further examination would be expected to evaluate how and why attributes change over a pattern of visits. As past investigations have appeared, this degree of mindfulness can either be created through the encounters of visits to the locale (Zhang, Fu, Cai,, \& Lu, 2014; Kim and Morrison, 2005) or by the impacts of initiated images, from advertisements or broad communications presentation (Gunn, 1972). One explanation might be because of the motivation behind the visit, specifically for Gasparilla or another reason.

\section{VIEW OF GASPARILLA VISITORS AND THE INDIVIDUALS WHO CAME FOR ANOTHER PURPOSE}

Like pre and post testing of first time and revisit guests, characteristics were likewise surveyed and positioned with respect to whether the respondent was coming to see the Tampa Gasparilla $(n=74)$, or for another reason $(n=84)$, on appearance (see Table 4) and on takeoff (see Table 4). A few items positioned high with both respondent examples on appearance; that Tampa has 'beautiful weather', has 'Many interesting local festivals/shows', and ' Attractive enough to tell others on your return '. A few qualities additionally scored low, for example, Tampa has ' Place to have meeting/exhibition ', ' Wide variety of products ', and 'Rich cultural heritage'. Mean contrasts were accounted for and applying the ttest investigation, measurable statistical significance were found between the two gatherings with the accompanying characteristics; Tampa has ' Lower prices/value for money' $(t=-0.036 ; p \leq 0.05)$, and ' Many places of interest to visit ' $(\mathrm{t}=0.076 \mathrm{p} \leq 0.05)$.

Table 4: PERCEPTIONS OF FIRST TIME AND REPEAT TRAVELLERS ON DEPARTURE FROM TAMPA (N=148)

\begin{tabular}{|c|c|c|c|c|c|c|c|}
\hline & \multicolumn{2}{|c|}{$\begin{array}{l}\text { First time travellers } n \\
=35\end{array}$} & \multicolumn{2}{|c|}{$\begin{array}{c}\text { Repeat } \\
\text { travellers } \mathrm{n} \\
=123\end{array}$} & \multirow[b]{2}{*}{$\begin{array}{c}\text { Mean } \\
\text { difference }\end{array}$} & \multirow[b]{2}{*}{$\begin{array}{c}\mathrm{t}- \\
\text { value }\end{array}$} & \multirow[b]{2}{*}{$\begin{array}{l}\text { Sig. (2- } \\
\text { tailed) at } \\
5 \%\end{array}$} \\
\hline & Mean & SD & Mean & SD & & & \\
\hline Beautiful Weather & 4.04 & .455 & 3.95 & .700 & 0.09 & .608 & .544 \\
\hline
\end{tabular}


Image Influence Based on Hallmark Event

\begin{tabular}{|c|c|c|c|c|c|c|c|}
\hline $\begin{array}{l}\text { Many interesting local } \\
\text { festivals/shows }\end{array}$ & 3.76 & .663 & 3.75 & .731 & 0.01 & .076 & .939 \\
\hline $\begin{array}{c}\text { Attractive enough to tell others } \\
\text { on your } \\
\text { return }\end{array}$ & 3.88 & .781 & 3.87 & .600 & 0.01 & .073 & .942 \\
\hline $\begin{array}{l}\text { Good quality tourist } \\
\text { information }\end{array}$ & 3.88 & .726 & 3.67 & .844 & 0.21 & 1.132 & .259 \\
\hline $\begin{array}{l}\text { Lower prices/value for } \\
\text { money }\end{array}$ & 3.16 & .987 & 3.53 & .772 & -0.37 & -.823 & .040 \\
\hline $\begin{array}{l}\text { Wide variety of } \\
\text { products }\end{array}$ & 3.20 & .913 & 3.33 & .844 & -0.13 & -.667 & .506 \\
\hline $\begin{array}{l}\text { Ease of accessibility/Transit } \\
\text { city }\end{array}$ & 3.56 & .961 & 3.53 & .782 & 0.03 & .177 & .860 \\
\hline Natural scenic beauty & 3.20 & .957 & 3.49 & .761 & -0.29 & -2.002 & .167 \\
\hline Rich cultural heritage & 3.18 & .946 & 3.31 & -0.11 & -0.11 & -.477 & .637 \\
\hline $\begin{array}{c}\text { Opportunity for } \\
\text { adventure/excitement }\end{array}$ & 3.52 & .872 & 3.23 & .808 & 0.29 & .593 & .106 \\
\hline $\begin{array}{c}\text { Place to have } \\
\text { meeting/exhibition }\end{array}$ & 3.28 & .792 & 3.17 & .686 & 0.11 & .707 & .481 \\
\hline Many places of interest to visit & 3.28 & 843 & 3.64 & .821 & -.036 & .076 & .047 \\
\hline Unique cuisine & 3.60 & .913 & 3.74 & .745 & -0.14 & -.382 & .412 \\
\hline $\begin{array}{l}\text { Good quality and easy } \\
\text { to find hotels }\end{array}$ & 3.52 & .918 & 3.59 & .789 & -0.07 & -.053 & .714 \\
\hline \multicolumn{8}{|c|}{ PERCEPTIONS OF TRAVELLERS BY PURPOSE OF TRIP ON ARRIVAL TO TAMPA (N=148) } \\
\hline & $\begin{array}{l}\text { First time } \\
\text { travellers } \\
\mathrm{n}=35\end{array}$ & $\begin{array}{c}\text { Repeat travellers } \mathrm{n} \\
=123\end{array}$ & & & & & \\
\hline & Mean & SD & Mean & SD & $\begin{array}{c}\text { Mean } \\
\text { difference }\end{array}$ & $\begin{array}{c}t- \\
\text { value }\end{array}$ & $\begin{array}{l}\text { Sig. (2- } \\
\text { tailed) at } \\
5 \%\end{array}$ \\
\hline Beautiful Weather & 4.03 & .563 & 3.8 & .609 & 0.23 & 1.536 & .127 \\
\hline $\begin{array}{l}\text { Many interesting local } \\
\text { festivals/shows }\end{array}$ & 3.53 & .712 & 3.64 & .739 & -0.11 & -.925 & .357 \\
\hline $\begin{array}{c}\text { Attractive enough to tell others } \\
\text { on your } \\
\text { return }\end{array}$ & 3.27 & .761 & 3.25 & .834 & 0.02 & .117 & .907 \\
\hline
\end{tabular}

Looking at the first-time and repeat travelers, and whether they were coming to see Gasparilla or not, this research suggests that the actual purpose of the visit (i.e. whether it was for Gasparilla or for some other purpose) does not have as significant an effect on the visitor's view of Tampa's destination attributes at this point in time, as the number of times they visit Tampa, although 60 of the Gasparilla respondents were in fact repeat visitors (see Table 5). A possible explanation could be that the visitor who does not wish to go to Gasparilla will have more opportunities to experience the various attributes.

There does appear however to be general agreement that Tampa has 'beautiful weather', has 'many interesting local festivals/shows', and is 'attractive enough to tell others on your return'. A common consensus also emerges that visitors look less at Tampa's destination image as a place with 'place to have meeting/exhibition ', ' wide variety of products ', and 'rich cultural heritage". 


\section{LIKELIHOOD OF REPEAT VISIT TO TAMPA}

Upon leaving Gasparilla, the respondents were asked about their likelihood of visiting Tampa within the next 6 months (see Table 5). Due to Tampa's close proximity to beautiful beaches, which accounts for a large portion of revenue from tourists (Visittampabay.com, 2020), repeat visits from cold weather locations will be common. Taking this into consideration, and by adding a time limitation to the repeat visit question, this can further highlight Tampa's attractiveness. Most first time and repeat travelers responded that they were likely to visit Tampa within the next 6 months, including those coming to see the Gasparilla and those coming for other reasons. Therefore, the respondent sample shows that actual visits and personal experiences from Tampa during this period have had a positive effect on the visitors. What is not known is the degree of influence the staging of Gasparilla had in influencing the traveler to visit Tampa again.

Table 5: RESPONDENTS AS FIRST-TIME AND REPEAT TRAVELLERS, AND PURPOSE OF VISIT TO TAMPA $(\mathrm{N}=158)$

\begin{tabular}{|c|c|c|c|}
\hline \multicolumn{4}{|c|}{ Purpose of Trip } \\
\hline & Gasparilla & Other & Total \\
\hline First time travelers & 14 & 21 & 35 \\
\hline Repeated travelers & 60 & 63 & 123 \\
\hline Total & 74 & 84 & 158 \\
\hline \multicolumn{4}{|c|}{ LIKELIHOOD OF VISITING TAMPA WITHIN THE NEXT 6 MONTHS } \\
\hline \multicolumn{4}{|l|}{$\begin{array}{l}\text { By First Time and } \\
\text { Repeat Travellers }\end{array}$} \\
\hline & Likely & Not Likely & Total \\
\hline First time travelers & 25 & 10 & 35 \\
\hline Repeated travelers & 99 & 21 & 120 \\
\hline Total & 124 & 31 & 155 \\
\hline \multicolumn{4}{|l|}{ By Purpose of Trip } \\
\hline & Likely & Not Likely & Total \\
\hline Gasparilla & 63 & 11 & 74 \\
\hline Other & 61 & 20 & 81 \\
\hline Total & 124 & 31 & 155 \\
\hline
\end{tabular}

\section{RESEARCH LIMITATIONS}

Basically, a glimpse of Tampa's image during the major annual hallmark event, there are no comparative data from previous Gasparilla events. There is additionally constrained information on guest profiles during Gasparilla to discover if those surveyed were representative of the entire population. As the questionnaire distribution was administered in one area so as to accomplish a more representative sample, this may not precisely mirror the various groupings that visited Tampa during Gasparilla.

\section{DISCUSSION}

Pictures will assume a significant factor in a guest's definitive choice to visit a locale. Created from existing research, this investigation took a look at the effect of a hallmark event on repeating visitation. In spite of the fact that Tampa may have a developed image of a beach destination, there is the expectation that the continuous advancement of Tampa's travel industry will additionally upgrade its destination image. For first-time visitors just as revisit tourists during Gasparilla, a few characteristics, for example, hospitality, weather, attractiveness of the destination, and festivals and shows scored high leaving Tampa. This has demonstrated that appearance to Tampa can improve its image and furthermore underpins past examinations that have proposed that tourist image is a powerful procedure and can be changed (Kim and Morrison, 2005). Even with revisit tourists to Tampa, guests keep on reevaluating their view on the destination, illustrating to the Tampa government that further positive image 
change is conceivable. While there were contrasts in view of those coming to attend Gasparilla and the individuals who desired another reason, on leaving no measurable contrasts were found. Accordingly, the job of the Gasparilla and future mega games as a system in actuating destination perception quality and image change, would require further examination. This examination has shown that, regardless of whether it is a pre-visit discernment or from real visits, the picture of Tampa being a destination to have a gathering or lead business is recommended and continues to improve.

Consequently, the legislature should now see approaches to fortify this message further, both provincially and universally. With a greater part of the respondents being revisit guests, the utilization of different media structures and correspondence channels ought to be inspected to gauge their viability on drawing in visitors for occasions, such as, Gasparilla, and for the travel industry when all is said in done. A well-planned marketing campaign and advertising strategy will help fortify Tampa's attractive traits, balancing its negative ones and bringing about an all the more well-designed tourism destination image, driving the potential for increasing visitation and tourism revenue.

\section{SOURCES OF FUNDING}

This research received no specific grant from any funding agency in the public, commercial, or not-for-profit sectors.

\section{CONFLICT OF INTEREST}

The author have declared that no competing interests exist.

\section{ACKNOWLEDGMENT}

None.

\section{REFERENCES}

[1] Beerli, A., and J. D. Martin. (2004). "Factors Influencing Destination Image." Annals of Tourism Research, 31 (3): 657-81.

[2] Campo-Martinez, S., Garau-Vadell, J. B., \& Martinez-Ruiz, M. P. (2010). Factors influencing repeat visits to a destination: The influence of group composition. Tourism Management, 31, 862-870.

[3] Funk, D., \& Bruun, T. (2007). "The Role of SocioPsychological and Culture-Education Motives in Marketing International Sport Tourism: A Cross-Cultural Perspective." Tourism Management, 28 (3): 806-19.

[4] Gallarza, M. (2002) Destination Image: Towards a Conceptual Framework. Annals of Tourism Research 29:56-78.

[5] Gartner, W. C. (1989). Tourism image: attribute measurement of state tourism products using multidimensional scaling techniques. Journal of Travel Research, 28: 16-20.

[6] Gartner, W. C. (1993). Image formation process. Journal of Travel and Tourism Marketing, 2: 191-216.

[7] Getz, D. (2008). Event tourism: Definition, evolution, and research. Tourism Management, 29 (3), $403-428$.

[8] Gunn C. A. (1972). Vacationscape - designing tourist regions, Second Edition. New York: Van Nostrand Remh.

[9] Hosany, S., Ekinci Y., \& Uysal M. (2006). Destination image and destination personality: an application of branding theories to tourism places. Journal of Business Research, 59(5):638-42.

[10] Kaplanidou, K., \& Gibson, H. J. (2010). Predicting behavioral intentions of active event sport tourists: The case of a small-scale recurring sports event. Journal of Sport \& Tourism, 15, 163-179.

[11] Kim, S. S., \& Morrison, A. M. (2005). Changes of images of South Korea among foreign tourists after the 2002 FIFA World Cup. Tourism Management, 26(2): 233-247. Tampa Gasparilla Committee (2003).

[12] King, C., Chen, N., \& Funk, D. C. (2012). Exploring Destination Image Decay: A Study of Sport Tourists' Destination Image Change After Event Participation. Journal of Hospitality \& Tourism Research.doi: $10.1177 / 1096348012461547$. 
[13] Konecknik, M., \& Gartner, W.C. (2007). Customer-based brand equity for a destination. Annals of Tourism Research. 34(2): 400-421.

[14] Tasci, A. D. A., and W. C. Gartner. (2007). "Destination Image and Its Functional Relationships.” Journal of Travel Research, 45: 413-25

[15] Zhang, H., Fu, X., Cai, A., \& Lu, L. (2014). "Destination Image and Tourist Loyalty: A Meta- Analysis." Tourism Management 40:213-23. 